\title{
Affective Characteristics Analysis: a Comparative Study between Elementary School of Indonesia and Thailand
}

\author{
Dwi Sulisworo, \\ Ahmad Dahlan University \\ Yogyakarta, Indonesia \\ 11wi.sulisworo@uad.ac.id
}

\author{
Ika Maryani $^{2}$ \\ Ahmad Dahlan University \\ Yogyakarta, Indonesia \\ 2ika_mail87@ymail.com \\ Preecha Roengsamut ${ }^{3}$ \\ Islamic Integrated Schools Network \\ Krabi, Thailand \\ 3saki391@gmail.com
}

\begin{abstract}
Indonesia and Thailand has many similarities in the education system; but the learning outcome is much different. The purpose of this study is to measure the affective domain of student in both countries. Comparing the similarity and differences of both countries would figure out the certain education policy for better understanding on education system improvements. This research combines qualitative and quantitative research methods using ex post facto approach. The result shows there was significance different on self-esteem, interest, and belief. Indonesia got higher score than Thailand for self-esteem and interest aspect. On the contrary, Thailand got higher score for belief aspect than Indonesia. Both, Indonesia and Thailand got no significance different for attitude. In total, there is no significance different between both countries on affective characteristics. Three factors considered gave effect to effective characteristics profile in both countries namely learning strategy, ICT use, and teacher and student interaction.
\end{abstract}

\section{Keywords: ASEAN; education; affective; learning; elementary education; learning taxonomy}

\section{INTRODUCTION}

ASEAN has big influence on the future human development of the world. The agreement among ASEAN country members on ASEAN Economic Community give new opportunities for close collaboration each other countries including on education quality improvement. As part of ASEAN, Indonesia and Thailand have same commitment for a better future generation [1-3]. In general, Indonesia and Thailand has many similarities in the education system. These similarities among other are in the education system level and the learning outcomes evaluation [2, 4]. Even both countries have similar education system; the learning outcome is much different. The study about this phenomenon will support the analysis of education policy for both countries and others ASEAN countries as well. In many studies showed that the mutual affect both cognitive and affective domains would figure the learning result and performance $[5,6]$.

There are many and varied factors that influence learning success. It is necessary to classify these variables to create a conceptualization on how students learn and succeed in their education $(5,6]$. This category has been widely known as cognitive and affective characteristics. There is a complex relationship between cognitive and affective characteristics that affect the characteristics of learning in the classroom [7, 8]. This will decide the success of student learning. Focusing on the education, preliminary education has an important role to the student character building future [9]. It is an important phase as students' foundation for their future success. Beside cognitive aspects, therefore the affective aspects become important to learning achievement. Those both aspects cannot separate exclusively. Put the affective aspect of learning goal for student activity at early education phases elementary education would give much benefit for the student. Some research showed that improving affective performance would improve cognitive performance. It is why the research on affective aspect at elementary school becomes important for the future education.

The study of affective domain is important because the cognitive and affective domains cannot be separated. A proper assessment of the affective domain would be essential to improve learning performance as the assessment of cognitive domain $[10,11]$. In fact, the affective domain assessment probably at some situation 
more important than cognitive; because the understanding of the students in the affective profile could help teachers to encourage students who tend to give up on the challenge of learning [12]. Another advantage of the affective domain assessment is the possibility as feedback for teachers in developing lesson plans that fit the needs of students [13]. Thus understanding on this aspect will be the basis of the monitoring of students during education. The purpose of this study is to measure the affective domain of student in both Indonesia and Thailand schools. Comparing the similarity and differences of both countries would figure out the certain education policy for better understanding on both education system improvements.

\section{THEORETICAL BACKGROUND}

Affective domain is a vague concept. This concept related to various aspects of teaching and learning $[8,12$, 14]. This is because most of the definitions of affective discuss the important psychological traits such as eagerness, self-esteem, and socialization, beliefs, and values [7, 15]. There are many studies showing the affective relate to the learning outcomes [7, 10, 15, 16]. The concept of an affective domain was studied and described by many experts e.g. Bloom, Khratwohl, and Anderson with different perspectives. The level of affective achievement could be grouped into four levels, namely receiving, responding, valuing, organizing, and characterizing [7]. While based on its characteristics, affective domain express on the attitude, self-concept, interest, and belief aspects.

\section{A. Affective Domain}

The origin of affective domain taxonomy includes five levels [13], from lowest to highest: receiving when students aware and attend to the instructional; responding when students react to events or instructional content; valuing when students show a voluntary commitment to instructional event or content; organization when students prove to internalize of the value system; and characterization when students consistently act in a value system [17-20].

Receiving refer to student awareness of the topic, stimuli, events or problems. It includes willing and ready to learn about it or respond to it $[18,21-23]$. That is the willingness of students to capture the certain phenomena stimulation. From the standpoint of learning, it is due to get, hold, and direct attention. Learning outcomes in this aspect revolve around the simple awareness associated with the process of selective attention. One example is how to concentrate attention to the phenomenon while it is in the learning process. During this phase, students will receive a variety of new ideas and attempt to understand it.

Responding associated with the active participation of students [18, 21-23]. At this level, students do not only attend for certain phenomena but also react to the phenomenon in several ways. Learning outcomes at this level emphasizes the approval in responding, willingness to respond voluntarily, or satisfaction in responding. Valuing associated with a particular value attached to the subject, object, phenomenon, or behavior [18, 22]. Valuing based on the internalizing of a set of values. An indication of these values is expressed in student behavior. At this level, students voluntarily manifest behaviors consistently with a certain confidence. For example, when students show behavior coming on time to school, submit assignments on time or not. Student shows valuing when he/ she consistently aware to time effectively to meet academic obligations.

Organization associated to bringing common diverse values, resolving conflicts between them, and began to build internally consistent value system [18, 21]. Thus, the emphasis is on comparing, connecting, and synthesizing values. Learning outcomes are the concern with the conceptualization value. It recognizes the responsibility of each person to improve human relations or with organizations such as developing the value system.

Characterization associated to value or a set of value $[21,23]$. This happens when the student's behavior is consistent and predictable as if the value adopted as their lifestyle. In other words, students have internalized the values in-depth so that it becomes their characteristics. Individuals who have had a value system would be able to control his behavior. Thus, the student's behavior became consistent, and predictable. A result of the study on this level includes a variety of activities, but the main emphasis is on student characteristics.

\section{B. Affective Characteristics}

The affective dimensions of students are categorized by characteristic values, anxiety, and interest, locus of control, attitudes, and preferences. The characteristics of the affective must: includes the essential features of feelings and emotions, be typical of the mind or behaviour of student, have the intensity of the strength of feeling, have the direction to positive/ negative or feeling orientation, and have a target that feeling directed [11, $17,18,24]$. In all this conceptualization, clearly the affective characterizes emotional learning reflected in the beliefs, values, interests, and behavior of students.

Affective domain includes the way in which students deal with anything emotionally for instant feelings, belief, appreciation, interest, spirit, and attitude. Affective learning about how students feel when they learn, as well as of the learning experience so that they can direct internalized attitudes, opinions, and behaviors for the future. It is also important to further clarify the concept of attitudes, interests, self-concept and values or beliefs because it will be a hub for the conceptualization of affective characteristics.

Generally, self-concept consists of two components: academic self-concept and non-academic self-concept. Academic self-concept includes subject areas and nonacademic self-concept includes social and physical selfconcept. Academic self-concept refers to how a person 
shows himself or his ability to meet the academic tasks compared to others involved in the same task [25, 26]. Attitude plays an important role in learning. Attitude has a positive correlation as predictors of achievement [27]. A positive attitude also has a strong influence on student motivation and desire to learn [16]. Interests associated with attention. A person who puts on a specific interest tends to pay attention $[11,16]$. Indicators of interest include feelings of love, interest, attention, satisfaction, the tendency to follow $[5,11,18]$. Self-concept or selfbelief is an individual evaluation of the strength ability and its weaknesses [5, 10, 26, 28]. Belief is a value about actions or behaviors on considering a good and a bad thing. Some indicators of belief categorized as important as honesty, integrity, justice, and freedom.

\section{METHODS}

This research combines qualitative and quantitative research methods using ex-post facto approach. The affective domain was measured by certain questionnaire using scale consists of 26 items put on a 5-point Likert scale. The statements consist of forward and reversed direction statement from "strongly agree" to "strongly disagree". Sample items are: "I understand and believe in the importance of objectives and learning contents" and "This subject is uninteresting for me". The reliability (Cronbach alpha) of the instrument was found equal to 0.83. Table 1 shows the questionnaire structure.

TABLE 1. QUESTIONNAIRE STRUCTURE

\begin{tabular}{|c|c|c|c|}
\hline No & Aspects & $\begin{array}{c}\text { No. of } \\
\text { Item }\end{array}$ & Symbols \\
\hline \multirow[t]{5}{*}{1} & Attitude/ Behaviors & & \\
\hline & $\begin{array}{l}\text { Attitudes toward objectives of the } \\
\text { study and learning content }\end{array}$ & 1 & $\mathrm{~A} 1$ \\
\hline & $\begin{array}{l}\text { Attitudes toward the way to learn } \\
\text { the learning material }\end{array}$ & 2 & $\mathrm{~A} 2, \mathrm{~A} 3$ \\
\hline & Attitudes toward teachers & 2 & $\mathrm{~A} 4, \mathrm{~A} 5$ \\
\hline & $\begin{array}{l}\text { Attitudes towards the efforts to } \\
\text { deepen a learning material }\end{array}$ & 1 & A6 \\
\hline \multirow[t]{4}{*}{2} & Self Esteem/ Value & & \\
\hline & $\begin{array}{l}\text { Choosing subjects which are easy } \\
\text { to understand }\end{array}$ & 2 & $\mathrm{~B} 1, \mathrm{~B} 2$ \\
\hline & Understanding subjects quickly & 2 & $\mathrm{~B} 3, \mathrm{~B} 4$ \\
\hline & $\begin{array}{l}\text { Showing subjects which are } \\
\text { difficult }\end{array}$ & 1 & B5 \\
\hline \multirow[t]{5}{*}{3} & Interest & & \\
\hline & Attention & 2 & $\mathrm{C} 1, \mathrm{C} 2$ \\
\hline & Relevance & 2 & $\mathrm{C} 3, \mathrm{C} 4$ \\
\hline & Confidence & 2 & $\mathrm{C} 5, \mathrm{C6}$ \\
\hline & Satisfaction & 2 & $\mathrm{C} 7, \mathrm{C} 8$ \\
\hline \multirow[t]{4}{*}{4} & Belief & & \\
\hline & Believe in success & 2 & D1, D2 \\
\hline & $\begin{array}{l}\text { Showing confidence in their } \\
\text { ability }\end{array}$ & 2 & D3, D4 \\
\hline & $\begin{array}{l}\text { Maintaining confidence in the } \\
\text { society expectations }\end{array}$ & 4 & $\begin{array}{r}\mathrm{D} 5, \mathrm{D} 6, \mathrm{D} 7, \\
\mathrm{D} 8\end{array}$ \\
\hline
\end{tabular}

The sampling technique in this study is purposive sampling technique. The sample schools are 3 from Indonesia (Yogyakarta Special Province) and 3 from Thailand (Songhkla and Krabi Provinces). All schools are elementary school level. The student number as participants are 68 and 126 from Indonesia and Thailand. The limitation number of student as participant (194 students) and of selected school (6 schools) would affect the result generalization. The statistical analysis used ANOVA with level of error $5 \%$.

\section{RESUlt AND DisCUSSION}

\section{A. Descriptive Analysis}

Table 2 shows the result of descriptive statistics for all affective characteristics. From column mean, the magnitude can be converted to maximum of 5 . Considering the number of item for each aspect as mention on table 1, each aspect can be compared.

TABLE 2. DESCRIPTIVE STATISTICS

\begin{tabular}{|c|r|c|r|r|r|r|r|}
\hline & \multirow{2}{*}{} & & \multirow{2}{*}{\begin{tabular}{c} 
Std. \\
\cline { 5 - 8 }
\end{tabular}} & $\mathrm{N}$ & Mean & $\begin{array}{c}\text { Skewness } \\
\text { Deviation }\end{array}$ & \multicolumn{2}{c|}{ Statistic } & $\begin{array}{c}\text { Std. } \\
\text { Error }\end{array}$ & Statistic & $\begin{array}{c}\text { Std. } \\
\text { Error }\end{array}$ \\
\hline Attitude & 194 & 21.6907 & 3.91585 & -.334 & .175 & .714 & .347 \\
\hline $\begin{array}{c}\text { Self- } \\
\text { esteem }\end{array}$ & 194 & 15.7320 & 2.96793 & .722 & .175 & .427 & .347 \\
\hline Interest & 194 & 25.9381 & 3.83687 & .518 & .175 & 1.144 & .347 \\
\hline Belief & 194 & 24.8969 & 4.01676 & .309 & .175 & -.288 & .347 \\
\hline $\begin{array}{c}\text { Valid N } \\
\text { (listwise) }\end{array}$ & 194 & & & & & & \\
\hline
\end{tabular}

Figure 1 below show the conversion result. From the figure, can be concluded the highest score to the lowest score are attitude (3.61), interest (3.24), self-esteem (3.15), and belief (3.11) out of 5 scales respectively. It can be seen that all affective characteristics are higher than 3 (neutral). Only attitude tend to reach 4 (agree) in average.

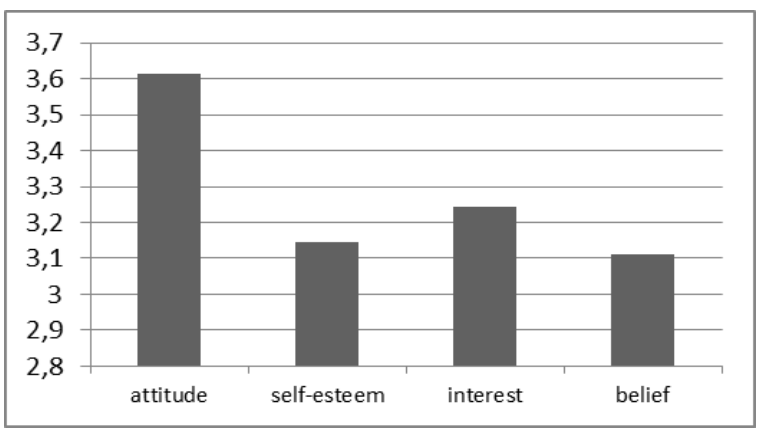

Fig. 1. The comparison affective characteristics score

From figure 1 can be said that elementary school students in both Indonesia and Thailand still need to be improved on their self-esteem and belief aspects. There is a possibility that the learning objectives related to these two characteristics are still lacking the focus of the learning process in schools. Deeper analysis can be seen from the value of skewness column. Those values are still in the range between -1.96 and +1.96 . This means that the affective characteristic for all aspects tend to be symmetrical. The same thing is on the values of the 
kurtosis column which are also in the range between 1.96 and +1.96 or mesocurtic curve. From these distributions (scewness and curtosis) can be said that the development of the affective domain measured in the affective characteristic both in Indonesia and Thailand tend to be normal. Figure 2 shows the normal curve for all aspects of the affective characteristics as a further explanation of the analysis of the mean value, skewness and kurtosis as described before.
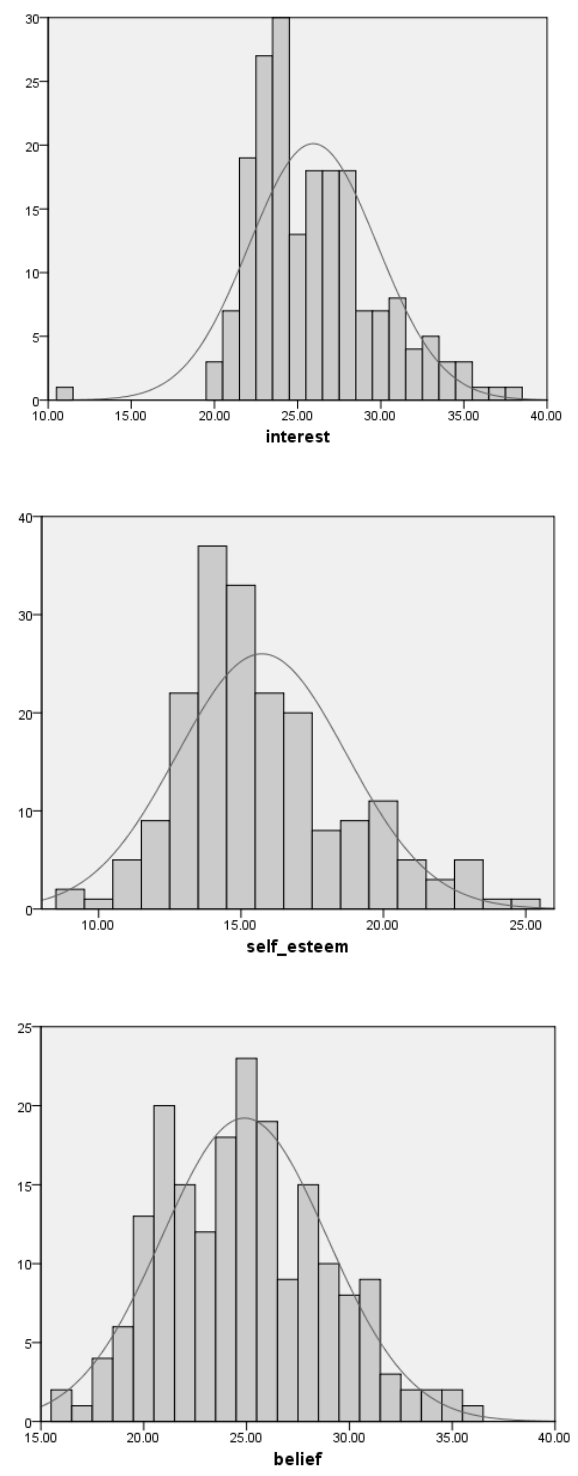

Fig. 2. The normal curve for affective characteristics

The descriptive statistics comparison between participants from Indonesia and Thailand is shown by table 3. The mean comparison on histogram is shown by figure 3 below. This figure was made by manipulating the mean value from table 3 . The scale was converted to out of 5 as Likert scale mentioned on method. From that figure, it can be seen there is differences for certain aspect between Indonesia and Thailand.
The further analysis from table 3 is to compare the mean and standard deviation. Comparative analysis at least can be seen from the value of mean and standard deviation. For the attitude aspect, both got relatively equal about 21, but different on standard deviation which Thailand students got standard deviation (4.21) than Indonesian students (3.33). It means that Thailand students are more heterogenic than Indonesian student on their attitude.

TABLE 3. DESCRIPTIVE STATISTICS COMPARISON

\begin{tabular}{|c|c|c|c|c|c|c|c|}
\hline & & \multirow[t]{2}{*}{$\mathrm{N}$} & \multirow[t]{2}{*}{ Mean } & \multirow[t]{2}{*}{$\begin{array}{c}\text { Std. } \\
\text { Deviation }\end{array}$} & \multirow[t]{2}{*}{$\begin{array}{l}\text { Std. } \\
\text { Error }\end{array}$} & \multicolumn{2}{|c|}{$\begin{array}{l}95 \% \text { Confidence } \\
\text { Interval for Mean }\end{array}$} \\
\hline & & & & & & $\begin{array}{l}\text { Lower } \\
\text { Bound }\end{array}$ & $\begin{array}{l}\text { Upper } \\
\text { Bound }\end{array}$ \\
\hline \multirow[t]{3}{*}{ attitude } & Indonesia & 68 & 21.8824 & 3.32574 & .40331 & 21.0774 & 22.6874 \\
\hline & Thailand & 126 & 21.5873 & 4.20908 & .37497 & 20.8452 & 22.3294 \\
\hline & Total & 194 & 21.6907 & 3.91585 & .28114 & 21.1362 & 22.2452 \\
\hline \multirow{3}{*}{$\begin{array}{c}\text { self- } \\
\text { esteem }\end{array}$} & Indonesia & 68 & 16.4265 & 3.62543 & .43965 & 15.5489 & 17.3040 \\
\hline & Thailand & 126 & 15.3571 & 2.48021 & .22095 & 14.9198 & 15.7944 \\
\hline & Total & 194 & 15.7320 & 2.96793 & .21308 & 15.3117 & 16.1522 \\
\hline \multirow[t]{3}{*}{ interest } & Indonesia & 68 & 27.4265 & 4.30313 & .52183 & 26.3849 & 28.4680 \\
\hline & Thailand & 126 & 25.1349 & 3.30903 & .29479 & 24.5515 & 25.7183 \\
\hline & Total & 194 & 25.9381 & 3.83687 & .27547 & 25.3948 & 26.4815 \\
\hline \multirow[t]{3}{*}{ belief } & Indonesia & 68 & 23.9853 & 4.72053 & .57245 & 22.8427 & 25.1279 \\
\hline & Thailand & 126 & 25.3889 & 3.50308 & .31208 & 24.7712 & 26.0065 \\
\hline & Total & 194 & 24.8969 & 4.01676 & .28839 & 24.3281 & 25.4657 \\
\hline \multirow[t]{3}{*}{ Total } & Indonesia & 68 & 89.7206 & 9.92336 & 1.20338 & 87.3186 & 92.1226 \\
\hline & Thailand & 126 & 87.4683 & 9.95404 & .88678 & 85.7132 & 89.2233 \\
\hline & Total & 194 & 88.2577 & 9.97591 & .71623 & 86.8451 & 89.6704 \\
\hline
\end{tabular}

For the self-esteem, both mean (16.43) and standard deviation (3.63) of Indonesian students are higher than Thailand students (15.36 and 2.48 for means and standard deviation). The same phenomena are found for the interest aspect. Student from Indonesia has higher mean (27.43) than student from Thailand (25.13). It is for the standard deviation too; 4.30 and 3.31 for Indonesia and Thailand. It can be said that Indonesian student more heterogenic on interest than Thailand student. On the contrary for the belief aspect, Thailand students got higher mean (25.39) and more homogeneous (3.50) than Indonesian student which the mean equal to 23.99 and standard deviation equal to 4.72). Figure 3 below shows the general profile of each item of the affective characteristics.

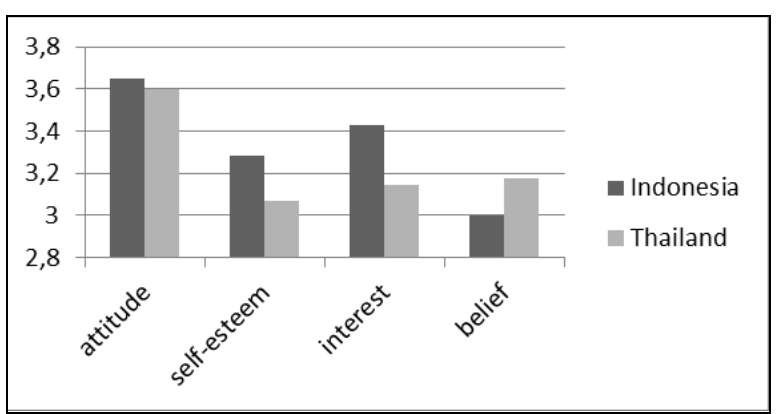

Fig. 3. The mean of affective characteristics comparison 
Figure 4 shows the average score of each item. From that figure, Indonesia and Thailand got similar pattern. As a conclusion, both countries face the same problem on learning performance especially for elementary school. There are many item got score below 3 . These would be the most prioritized to improve on their education system.

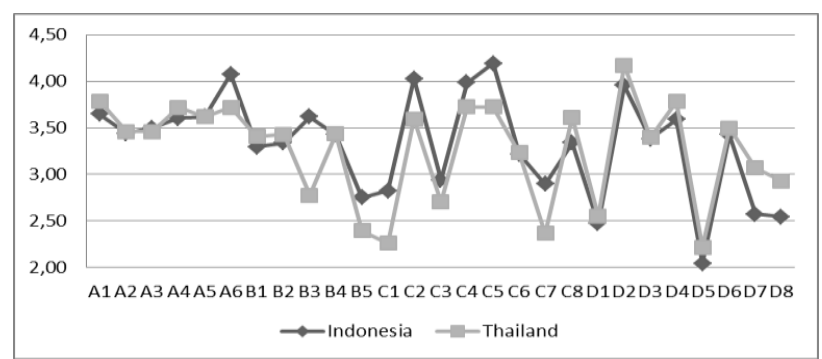

Fig. 4. The affective characteristics pattern of Indonesia and Thailand students

\section{B. Analysis of Variance}

Even though all aspects of affective characteristics can be explained by table 3 , the differences should be checked whether it is significance or not using ANOVA as shown by table 4 . From table 4 , there is significance different on self-esteem, interest, and belief. Indonesia got higher score than Thailand for self-esteem and interest aspect. On the contrary, Thailand got higher score for belief aspect than Indonesia. Both, Indonesia and Thailand got no significance different for attitude. In total, surprisingly there is no significance different between Indonesia and Thailand for affective characteristics (see the last row and column).

Deeper analysis to find out the explanation could be traced from the observation directly at the school activity. Attitude aspect is expressed on the student-teachermaterial interaction. Almost all school in both Thailand and Indonesia use similar learning strategy i.e. direct lesson instruction. It is the one way learning. Many studies showed that this strategy does not motivate students on their social skill rather than cooperative or collaborative learning strategy. Learning achievement is measured by knowledge acquisition. The effect of this strategy also can be seen from the lower mean of selfesteem. Teacher is being center of learning. This approach tends student got lower self-esteem. Students would have high dependence to the teacher for their learning.
TABLE 4. ANALYSIS OF VARIANCE

\begin{tabular}{|c|c|c|c|c|c|c|}
\hline & & $\begin{array}{c}\text { Sum of } \\
\text { Squares }\end{array}$ & $\mathrm{df}$ & $\begin{array}{c}\text { Mean } \\
\text { Square }\end{array}$ & $\mathrm{F}$ & Sig. \\
\hline \multirow[t]{3}{*}{ Attitude } & $\begin{array}{c}\text { Between } \\
\text { Groups }\end{array}$ & 3.845 & 1 & 3.845 & .250 & .618 \\
\hline & $\begin{array}{l}\text { Within } \\
\text { Groups }\end{array}$ & 2955.599 & 192 & 15.394 & & \\
\hline & Total & 2959.443 & 193 & & & \\
\hline \multirow[t]{3}{*}{$\begin{array}{c}\text { Self- } \\
\text { esteem }\end{array}$} & $\begin{array}{c}\text { Between } \\
\text { Groups }\end{array}$ & 50.501 & 1 & 50.501 & 5.878 & .016 \\
\hline & $\begin{array}{l}\text { Within } \\
\text { Groups }\end{array}$ & 1649.561 & 192 & 8.591 & & \\
\hline & Total & 1700.062 & 193 & & & \\
\hline \multirow[t]{3}{*}{ Interest } & $\begin{array}{c}\text { Between } \\
\text { Groups }\end{array}$ & 231.919 & 1 & 231.919 & 17.065 & .000 \\
\hline & $\begin{array}{l}\text { Within } \\
\text { Groups }\end{array}$ & 2609.339 & 192 & 13.590 & & \\
\hline & Total & 2841.258 & 193 & & & \\
\hline \multirow[t]{3}{*}{ Belief } & $\begin{array}{c}\text { Between } \\
\text { Groups }\end{array}$ & 87.008 & 1 & 87.008 & 5.519 & .020 \\
\hline & $\begin{array}{l}\text { Within } \\
\text { Groups }\end{array}$ & 3026.930 & 192 & 15.765 & & \\
\hline & Total & 3113.938 & 193 & & & \\
\hline \multirow[t]{3}{*}{ Total } & $\begin{array}{c}\text { Between } \\
\text { Groups }\end{array}$ & 224.049 & 1 & 224.049 & 2.266 & .134 \\
\hline & $\begin{array}{l}\text { Within } \\
\text { Groups }\end{array}$ & 18983.064 & 192 & 98.870 & & \\
\hline & Total & 19207.113 & 193 & & & \\
\hline
\end{tabular}

There was a phenomenon for other information related to this issue. Differences occur in the learning process of the two countries is about the readiness of teachers. Teachers in Thailand less optimize the use of media; lesson planning is not well prepared. Thailand teachers focus more on how to serve the needs of students during the school day, such as serving lunch, assisting students in work on the problems, and helping students' learning difficulties. Instead of teachers in Indonesia are preparing instructional media including ICT-based media at the beginning of learning. This impact probably appears on the level of interaction of teachers and students during the school day. Teachers in Thailand are considered as second parents for students and instead of in Indonesia are also similar but there is a presumption that there is a higher level of formality. But, the result relatively similar i.e students from both countries raise same score on attitude aspect. Probably the most influenced reason is the learning strategy. It is suggested to the school to introduce the new learning strategy as an alternative one. At the national policy, basically both Education Ministries have launched the competence based curriculum for all education level; but it still need a view time for the implementation awareness at elementary education.

The students interest aspect to learning can be traced from the learning media or learning strategy as well. As mention before, almost teacher at studied school in Indonesia try to embed ICT on learning even the strategy still one way direction. On the contrary, teachers from Thailand use more conventional teaching and learning strategy. From the observation, it was found that teacher in Thailand less use media on learning and relatively lesson planning was not well prepared. Thailand teachers 
focused more on how to serve the needs of students during the school day, such as serving lunch, assisting students in work on the problems, and helping students' learning problem. Different teacher action on manage learning activities affected the student interest on learning.

As mention at the previous paragraph, teachers in Thailand are closer to students than ones in Indonesia. For instant, teacher in Thailand always ready at the classroom to nurture student activities. They do not have special teacher room. The classroom becomes teacher room. On the other side, in Indonesia teachers have individual room for their privacy but the impact is they less interaction contact to student. The implication appears on the level of interaction of teachers and students during the school day. Teachers in Thailand are considered as second parents for students and instead of in Indonesia are also similar but there is a presumption that there is a higher level of formality on their interaction during at school. These phenomena can explain why student from Thailand got higher belief aspect score than student from Indonesia.

\section{CONCLUSION}

This research compares the affective characteristics of elementary education student between Indonesia and Thailand school. There are four aspects considered as affective characteristics, i.e. attitude, self-esteem, interest, and belief. Analysis using ANOVA technique found that there is significance different on self-esteem, interest, and belief. Indonesia got higher score than Thailand for selfesteem and interest aspect. On the contrary, Thailand got higher score for belief aspect than Indonesia. Both, Indonesia and Thailand got no significance different for attitude. In total, there is no significance different between Indonesia and Thailand on affective characteristics.

Three factors considered gave effect to effective characteristics profile in both Indonesia and Thailand is learning strategy, ICT use, and teacher and student interaction. Direct lesson instruction strategy usage at almost schools caused the student attitude positively but self-esteem negatively. It will be a serious problem for future elementary education. ICT use as learning media on school would enhance student interest on learning. The school management should pay an attention on the teacher ICT literacy to support ICT based media development and use. On top of that, teacher and student interaction would be the most important factor. Good interaction would bring many opportunities to student learning improvement.

From the observation, the management should improve many education aspects. To meet this phenomenon, education policy makers from both countries have launched several policies to improve the education outcome for instant the competence based curriculum implementation. Unfortunately, this policy has not embraced effectively to all schools levels.

\section{Acknowledgment}

The research is funded by Research and Development Board of Ahmad Dahlan University under Collaboration Research Grant for year 2015-2016.

\section{References}

[1] H. Firman, \& B. Tola, "The Future of Schooling in Indonesia. Journal of International Cooperation in Education," vol. 11, no. 1, pp. 71-84.

[2] P. Hallinger, \& D. A. Bryant, "Synthesis of findings from 15 years of educational reform in Thailand: Lessons on leading educational change in East Asia," International Journal of Leadership in Education, vol. 16, no. 4, pp. 399-418, 2013.

[3] C. Tan, "Educative Tradition and Islamic Schools in Indonesia," Journal of Arabic and Islamic Studies, vol. 14, pp. 47-62, 2014.

[4] T. Zulfikar, "The Making of Indonesian Education: An Overview on Empowering Indonesian Teachers," Journal of Indonesian Social Sciences and Humanities, vol. 2, pp. 13-39, 2009.

[5] B. Bodroža, "Cognitive and affective reactions to success and failure - the quality of feedback as the determinant of selfverifying and self-enhancing motivation," Psihologija, vol. 44, no. 2, pp. 149-166, 2011.

[6] G. J. Hwang, \& H. F. Chang, "A formative assessment-based mobile learning approach to improving the learning attitudes and achievements of students," Computers and Education, vol. 56, no. 4, pp. 1023-1031, 2011.

[7] C. A. Oppong, "Cognitive and Affective Characteristics of History Students of the University of Cape Coast," International Journal of Scientific and Research Publication, vol. 4, no. 10, pp. 1-7, 2014.

[8] M. M. T. Rodrigo, E. S. Tabanao, R. S. Baker, M. C. Jadud, A. C. M. Amarra, T. Dy, ... J. O. Sugay, "Affective and behavioral predictors of novice programmer achievement," ACM SIGCSE Bulletin, vol. 41, no. 3, pp. 156, 2009.

[9] P. Dinis, E. S. Calvo, \& P. Albergaria-almeida, Teaching Practices in Primary and Secondary Schools in Europe: Insights from Large-Scale Assessments in Education, Luxembourg: Publications Office of the European Union, 2015.

[10] A. Kumari, \& D. S. Chamundeswari, "Self-Concept and Academic Achievement of Students at the Higher Secondary Level," Journal of Sociological Research, vol. 4, no. 2, pp. 105114, 2013.

[11] E. Rimland, "Assessing Affective Learning Using a Student Response System," Libraries and the Academy, vol. 13, no. 4, pp. 385-401, 2013.

[12] L. K. Y. Li, "A Study of the Attitude, Self-efficacy, Effort and Academic Achievement of CityU Students towards Research Methods and Statistics". Discovery SS Student E - Journal, vol. 1, pp. 154-183, 2012.

[13] OECD, OECD Guidelines on Measuring Subjective Well-being. Report. 2013.

[14] S. A. Chamberlin, "A review of Instruments Created to Assess Affect in Mathematics," Journal of Mathematics Education, vol. 3, no. 1, pp. 167-182, 2010.

[15] A. Veloo, R. M. Ali \& H. N. Krishnasamy, "Affective determinants of Additional Mathematics achievement in Malaysian Technical Secondary Schools," Proceedia-Social and Behavioral Sciences, vol. 112, pp. 613-620, 2014.

[16] P. Kpolovie, A. Joe, \& T. Okoto, "Academic Achievement Prediction: Role of Interest in Learning and Attitude towards School," International Journal of Humanities Social Sciences and Education, vol. 1, no. 11, pp. 73-100, 2014.

[17] L. W. Anderson, \& J. C. Anderson, "Affective Assessment Is Necessary and Possible," Educational Leadership, vol 39, pp. 524-526, 1982. 
[18] B. L. Boyd, K. E. Dooley, \& S. Felton, "Measuring Learning in the Affective Domain Using Reflective," Journal of Agricultural Education, vol. 47, no. 3, pp. 24-32, 2006.

[19] C. W. Ford, Clinical Education for the allied health professions, St. Louis: CV Mosby Company, 1978

[20] J. G. McNabb, "Key Affective Behaviors of Students as Identified by a Select Group of Secondary School Teachers Using the SCANS Categories," Journal of Industrial Teacher Education, vol. 34, no. 4, pp. 29-41, 1997.

[21] K. N. Allen, \& B. D. Friedman, "Affective learning: A taxonomy for teaching social work values," Journal of Social Work Values and Ethics, vol. 7, no. 2, 2010.

[22] I. Doherty, "Professional Development: Designing for the Cognitive and Affective Domains," Journal of Learning Design, vol, 7, no. 3, pp. 1-15, 2014.

[23] K. G. Griffith, A. D. Nguyen, \& E. Ed, “Are Educators Prepared to Affect the Affective Domain?" National Forum of Teacher Education Journal, vol. 16, no. 3, pp. 1-4, 2006.
[24] E. Yavuz, S. Bayram, \& L. Deniz, "Factors That Influence Academic Achievement," International Journal of Instruction, vol. 1, no. 1 , pp. 31-47, 2008

[25] J. G. Freeman, “Academic Achievement, Academic Self-Concept, and Academic Motivation of Immigrant Adolescents in Greater Toronto Area Secondary Schools," Journal of Advance Academic, vol. 19 , no. 4, pp. 700-743, 2008.

[26] J. Green, G. Nelson, A. J. Martin, \& H. Marsh, "The causal ordering of self-concept and academic motivation and its effect on academic achievement," International Education Journal, vol. 7, no. 4 , pp. 534-546, 2006.

[27] C. C. Shih, \& J. Gamon, "Web-Based Learning: Relationships Among Student Motivation, Attitude, Learning Styles, And Achievement," Journal of Agricultural Education, vol. 42, no. 4, pp. 12-20, 2001.

[28] N. Y. Wong, "The relationship among mathematics achievement, affective variables and home background," Mathematics Education Research Journal, vol. 4, no. 3, pp. 32-42, 1993. 